\title{
Effect of pregrazing herbage mass on methane production, dry matter intake, and milk production of grazing dairy cows during the mid-season period ${ }^{1}$
}

\author{
C. M. Wims, ${ }^{*} †$ M. H. Deighton, ${ }^{*}$ E. Lewis, ${ }^{*}$ B. O’Loughlin, ${ }^{*}$ L. Delaby, $\ddagger$ T. M. Boland, $†$ and M. O’Donovan ${ }^{* 2}$ \\ ${ }^{*}$ Grassland Science Research Department, Animal and Grassland Research and Innovation Centre, Teagasc, Moorepark, Fermoy, \\ Co. Cork, Ireland \\ †School of Agriculture, Food Science and Veterinary Medicine, University College Dublin, Belfield, Dublin 4, Ireland \\ fInstitut National de Recherche Agronomique, Unité Mixte de Recherche Production du Lait, St-Gilles, France
}

\begin{abstract}
Increasing milk production from pasture while increasing grass dry matter intake (GDMI) and lowering methane $\left(\mathrm{CH}_{4}\right)$ emissions are key objectives of low-cost dairy production systems. It was hypothesized that offering swards of low herbage mass with increased digestibility leads to increased milk output. A grazing experiment was undertaken to investigate the effects of varying levels of $\mathrm{HM}$ on $\mathrm{CH}_{4}$ emissions, GDMI and milk production of grazing dairy cows during the mid-season grazing period (June to July). Prior to the experiment, 46 Holstein-Friesian dairy cows (46 d in milk) were randomly assigned to 1 of 2 treatments $(\mathrm{n}=23)$ in a randomized block design. The 2 treatments consisted of 2 target pregrazing HM: 1,000 kg of dry matter (DM)/ ha (low herbage mass, LHM) or 2,200 kg of DM/ha (high herbage mass, HHM). The experimental period lasted 2 mo from June 1 until July 31. Within the experimental period, there were 2 measurement periods, measurement 1 (M1) and measurement 2 (M2), where $\mathrm{CH}_{4}$ emissions, GDMI, and milk production were measured. Mean herbage mass throughout the measurement periods was $1,075 \mathrm{~kg}$ of $\mathrm{DM} / \mathrm{ha}$ and $1,993 \mathrm{~kg}$ of DM/ ha for the LHM and HHM treatments, respectively. Grass quality in terms of organic matter digestibility was significantly higher for the LHM treatment in M2 $(+12 \mathrm{~g} / \mathrm{kg}$ of DM). In M1, the effect of herbage mass on grass quality was approaching significance in favor of the LHM treatment. Herbage mass did not significantly affect milk production during the measurement periods. Cows grazing the LHM swards had increased GDMI in M1 (+1.5 kg of DM) compared with cows grazing the HHM swards; no difference in GDMI was observed in M2. Grazing HHM swards increased $\mathrm{CH}_{4}$ production
\end{abstract}

\footnotetext{
Received March 9, 2010.

Accepted July 5, 2010.

${ }^{1}$ Funding for this research was provided under the National Development Plan, through the Research Stimulus Fund, administered by the Department of Agriculture, Fisheries and Food, Ireland (\#RSF 07 517).

${ }^{2}$ Corresponding author: michael.odonovan@teagasc.ie
}

per cow per day $(+42 \mathrm{~g})$, per kilogram of milk yield $(+3.5 \mathrm{~g} / \mathrm{kg}$ of milk), per kilogram of milk solids $(+47$ $\mathrm{g} / \mathrm{kg}$ of milk solids), and per kilogram of GDMI $(+3.1$ $\mathrm{g} / \mathrm{kg}$ of GDMI) in M2. Cows grazing the HHM swards lost a greater proportion of their gross energy intake as $\mathrm{CH}_{4}$ during both measurement periods $(+0.9 \%$ and $+1 \%$ for M1 and M2, respectively). It was concluded that grazing LHM swards would increase grass quality with a concurrent reduction in $\mathrm{CH}_{4}$ emissions.

Key words: methane, herbage mass, dairy cow, grazing

\section{INTRODUCTION}

Under the Kyoto Protocol of 1997, Ireland has committed to reducing its total greenhouse gas (GHG) emissions to 1990 levels. Irish agricultural GHG emissions have decreased by approximately $8 \%$ compared with 1990 levels. This was achieved through reductions in livestock numbers and fertilizer nitrogen use. The agriculture sector remains Ireland's largest producer of GHG emissions, accounting for $26 \%$ of total emissions in 2007 (McGettigan et al., 2009). The dairy sector alone is responsible for approximately $10 \%$ of total GHG emissions (Lovett et al., 2008) and with projected increases in national milk output (Lips and Reider, 2005) this contribution will potentially increase. Approximately $50 \%$ of GHG emissions associated with Irish dairy production are in the form of methane $\left(\mathrm{CH}_{4}\right.$; Casey and Holden, 2005). The reliance of the predominantly spring-calving Irish dairy herd on grazed grass necessitates the development of grass-based $\mathrm{CH}_{4}$ mitigation strategies to aid Ireland in meeting its GHG emissions reduction targets. O'Brien et al. (2010) has demonstrated that grass-based systems can achieve both higher profitability and reduced GHG emissions compared with other farm systems.

Monteny et al. (2006) proposed a $\mathrm{CH}_{4}$ mitigation strategy in ruminants by increasing the ruminal production of propionate through improved feed intake and feed composition. Methane yield from forage digestion averages about $20 \mathrm{~g}$ of $\mathrm{CH}_{4} / \mathrm{kg}$ of DMI, with the $\mathrm{CH}_{4}$ 
derived from digestion of DM, primarily in the rumen (Hammond et al., 2009). In a large data set, Hammond et al. (2009) found that the chemical composition of fresh ryegrass pasture was able to explain only $20 \%$ of the variation in $\mathrm{CH}_{4}$ yield, with variation in $\mathrm{CH}_{4}$ production best explained by DMI. Beever (1993) suggested that lower $\mathrm{CH}_{4}$ production might be expected from immature pasture with a high NFC and low NDF content, and a higher $\mathrm{CH}_{4}$ yield from more mature, fibrous pasture.

Striking the correct balance between herbage quality and quantity is a key driver in grass-based production systems, with pregrazing herbage mass (HM) and postgrazing sward height being 2 critical factors that influence herbage intake and animal performance. Maintaining higher HM swards can reduce sward quality and feeding value, leading to a depression in grass dry matter intake (GDMI) according to O'Donovan and Delaby (2008), mediated through a lower proportion of leaf and a higher proportion of stem and senescent material in the grazing sward (Holmes et al., 1992). On the other hand, high grazing intensity in the spring and early summer period can produce low HM swards with a higher proportion of green leaf according to Stakelum and Dillon (2007). Indeed, Mayne et al. (1987) reported that low grazing pressure would significantly reduce the organic matter digestibility (OMD) of swards from mid-June onward. Holmes et al. (1992) reported that high HM swards have lower digestibility than low HM swards and that at a common daily herbage allowance (DHA) milk yield per cow will be depressed with high HM swards.

The objective of this study was to examine the effects of pregrazing $\mathrm{HM}$ on GDMI, $\mathrm{CH}_{4}$ emissions, and milk production and composition during the mid-season (June-July) grazing period.

\section{MATERIALS AND METHODS}

The experiment was conducted at Moorepark Dairy Production Research Centre, Fermoy, Co. Cork, Ireland $\left(50^{\circ} 09^{\prime} \mathrm{N} ; 8^{\circ} 16^{\prime} \mathrm{W}\right)$. The soil type was a free-draining acid brown earth of sandy loam-to-loam texture. The area used was under permanent pasture with a predominantly perennial ryegrass sward (Lolium perenne L.). The swards were, on average, 8 yr old. Three late-heading diploid cultivars (Twystar, Cornwall, and Gilford) were initially sown.

\section{Treatments and Experimental Design}

The experiment investigated the effect of offering 2 target levels of pregrazing HM (1,000 and 2,200 kg of $\mathrm{DM} /$ ha) on milk production, milk composition, GDMI, and $\mathrm{CH}_{4}$ emissions. The experiment was conducted as a randomized block design over a 2 -mo period. The experimental period lasted from June 1 to July 31, 2009. Grass dry matter intake, $\mathrm{CH}_{4}$ production, milk production and composition, BW, and BCS were measured twice during this period, measurement 1 (M1; June 21-26) and measurement 2 (M2; July 12-17). All sward measurements reported within this paper refer to the above-mentioned measurement periods. This experiment was part of a larger system study that was imposed from April 13 to November 20, 2009.

\section{Animals}

All animals used in this experiment were cared for in accordance with the European Community Directive, 80-609-EC (European Community, 2002). Treatments were imposed upon the experimental cows from April 13 onward. Prior to this date, the cows grazed as a single herd from calving (46 DIM) and were offered $3 \mathrm{~kg}$ of concentrate DM/cow daily. Before the experiment, 46 Holstein-Friesian dairy cows (14 primiparous and 32 multiparous) were selected and blocked using DIM (46; SEM 5.1) and lactation number (2.7; SEM 1.3). The following data were collected during the 3 wk before application of treatments: milk yield (25.5 kg; SEM 2.4), BW (493 kg; SEM 8.6), and BCS (2.7; SEM 0.5). Animals were randomly assigned to $2 \mathrm{HM}$ treatments: $1,000 \mathrm{~kg}$ of DM/ha (low HM, LHM) or 2,200 kg of DM/ha (high HM, HHM). Herbage mass was calculated above $4 \mathrm{~cm}$.

\section{Grazing Management}

The experimental grazing area comprised 16.4 ha divided into 12 paddocks. Paddocks were divided into 2 sub-paddocks and permanently fenced. Sub-paddocks were randomly assigned to individual treatments, with 12 sub-paddocks per treatment. A similar grazing area (farmlet) was available to each treatment (8.2 ha per treatment). The entire experimental area was grazed once (February 23 to April 7) before commencing the HM experiment. During this period, the differences in pregrazing HM were created by varying the interval between initial grazing and applying the experimental grazing treatment. The HHM swards were grazed initially, followed by the LHM swards, thus creating different regrowth intervals. These differences in HM were maintained throughout the grazing season enabling the cumulative effect of the HM to be examined in this experiment. Both treatments were managed independently. Daily herbage allowance was governed using a postgrazing sward height of 4 to $4.5 \mathrm{~cm}$. To calculate DHA, the area offered to the herd was multiplied by the 
HM to give the DHA offered to each animal. Animals remained in sub-paddocks for 24- to 36 -h periods; however, the area grazed daily or the effective grazing area differed between treatments. Swards were not topped (mechanically conditioned) during the experiment.

\section{Sward Measurements}

Herbage mass $(>4 \mathrm{~cm})$ was calculated by cutting 4 strips $(1.2 \mathrm{~m} \times 10 \mathrm{~m})$ with a motor Agria (Etesia UK Ltd., Warwick, UK) before each paddock was grazed. Ten grass height measurements were recorded before and after harvesting on each cut strip using a folding pasture plate meter with a steel plate (diameter 355 $\mathrm{mm}$ and $3.2 \mathrm{~kg} / \mathrm{m}$; Jenquip, Fielding, New Zealand). All mown herbage from each strip was collected, weighed, and subsampled. A further subsample of $0.1 \mathrm{~kg}$ (fresh weight) of the herbage sample from each strip was dried for $16 \mathrm{~h}$ at $90^{\circ} \mathrm{C}$ for $\mathrm{DM}$ determination.

Pregrazing sward height was measured daily throughout the experimental period by recording approximately 30 heights per treatment across the 2 diagonals of each paddock using a folding pasture plate meter (as described above). Following grazing, postgrazing sward heights were also recorded for each treatment, as described previously.

Leaf, stem, and dead content in the upper and lower sward horizon $(>4 \mathrm{~cm}$ and $<4 \mathrm{~cm}$ ) were measured during the experimental period. Herbage representative of that available to the grazing animal was cut to ground level using hand shears. The herbage was then separated into its lower and upper sward horizon $(>4 \mathrm{~cm}$ and $<4 \mathrm{~cm}$ ). Each individual layer was manually separated into leaf blades, pseudostem (including stems and flower heads if present), and dead material. Then, each layer was dried for $16 \mathrm{~h}$ at $90^{\circ} \mathrm{C}$ for $\mathrm{DM}$ determination. This allowed the leaf, stem, and dead proportions to be calculated. Leaf, stem, and dead proportions above $4 \mathrm{~cm}$ were then multiplied by DHA to calculate the proportion of leaf, stem, and dead material offered to the grazing animals.

\section{Animal Measurements}

Milking took place at 0700 and $1600 \mathrm{~h}$ daily. Individual milk yields $(\mathrm{kg})$ were recorded at each milking (Dairymaster, Causeway, Co. Kerry, Ireland). Milk fat, protein, and lactose concentrations were calculated weekly from one successive evening and morning milking sample for each animal. A Milkoscan 203 (Foss Electric, Hillerød, Denmark) was used to determine the concentrations of these constituents in the milk. Solidscorrected milk yield was calculated using the equation of Tyrrell and Reid (1965).
Body weight was recorded during each measurement period using electronic portable weighing scales and the Winweigh software package (Tru-Test Ltd., Auckland, New Zealand). Body condition score was also recorded during each measurement period. Body condition was scored by one experienced, independent observer throughout the experiment on a scale of 0 to 5 (Lowman et al., 1976).

\section{Methane Production}

Methane production was measured twice during the experiment: M1 (June 21-26) and M2 (July 12-16). The $\mathrm{CH}_{4}$ emission of the cow was determined by using the emissions from ruminants using a calibrated tracer (ERUCT) technique. To have an accurate assessment of methane production from each animal we set a limit of a minimum of $4 \mathrm{~d}$ of accurate methane measurements from each animal. Animals that did not meet this requirement were not used in the statistical analysis. This resulted in measurements being used from 13 and 16 cows on the HHM and LHM treatments, respectively, in M1 and 17 and 18 cows on the HHM and LHM treatments, respectively, in M2. This study used sulfur hexafluoride $\left(\mathrm{SF}_{6}\right)$ tracer gas as described by Johnson et al. (2007), with equipment modifications for freeranging dairy cattle.

Trace gas permeation tubes were filled with approximately $2.5 \mathrm{~g}$ of $\mathrm{SF}_{6}$ in January 2009. Linear $\mathrm{SF}_{6}$ emission was confirmed via gravimetric weighing to produce an 8-point regression curve $\left(\mathrm{r}^{2}>0.999\right)$ during incubation in $39^{\circ} \mathrm{C}$ air at the trial site. Tubes were blocked by emission rate (mean $7.22 \mathrm{mg} / \mathrm{d}$; SE 0.19) and randomly allocated to both experimental treatment and cow within treatment. Tubes were dosed orally $10 \mathrm{~d}$ before commencement of sample collection.

Expired and eructated gases along with ambient air were drawn into the evacuated collection canister via a halter-mounted tube looped above the cow's mouth and nostrils. The rate of sample collection was restricted to $0.5 \mathrm{~mL} / \mathrm{min}$ via passage through a $50-\mathrm{mm}$ length of stainless steel capillary tubing with an internal diameter of $12.7 \mu \mathrm{m}$ (Valco Instruments Co. Inc., Houston, TX) crimped at several points and calibrated using a digital flow meter (Cole-Parmer Instrument Co., Vernon Hills, IL). Each precalibrated restriction tube was fixed into a proprietary aluminum brace to prevent loss of calibration during the collection period. Gases were sampled for 5 consecutive 24-h periods using an initial canister vacuum 900 mbar below atmospheric pressure. A 120-h continuous sampling period was achieved during the measurement period using a rotation of 3 canisters per cow. Sample concentrations of $\mathrm{SF}_{6}$ and $\mathrm{CH}_{4}$ were determined via gas chromatography as described by Johnson 
et al. (2007) using a Varian 3800 gas chromatograph (Varian Inc., Palo Alto, CA).

\section{Intake Measurement}

During the periods of $\mathrm{CH}_{4}$ sampling, individual GDMI was also estimated using the $n$-alkane technique (Mayes et al., 1986) as modified by Dillon and Stakelum (1989). All cows were dosed twice daily for $12 \mathrm{~d}$ before both morning and evening milkings with a paper pellet (Carl Roth, GmbH, Karlesruhe, Germany) containing $500 \mathrm{mg}$ of dotriacontane $\left(\mathrm{C}_{32}\right.$-alkane). From d 7 to 12 of dosing, feces samples were collected from each cow twice daily before both morning and evening milking and stored at $-20^{\circ} \mathrm{C}$. The feces samples were then thawed and bulked (10 g of each collected sample) by cow and dried for 48 $\mathrm{h}$ in a $60^{\circ} \mathrm{C}$ oven. Samples were then milled through a 1-mm screen and stored for chemical analysis. During the period of feces collection, the diet of the animals was also sampled. Herbage samples were manually collected with a Gardena hand shears (Accu 60, Gardena International GmbH, Ulm, Germany) following close observation of the previous defoliation height to collect a representative sample of the herbage grazed. Herbage samples were frozen at $-20^{\circ} \mathrm{C}$ following collection. Herbage samples were then bowl-chopped, freeze-dried, and milled through a 1-mm screen before chemical analysis. The ratio of herbage $\mathrm{C}_{33}$ to dosed $\mathrm{C}_{32}$ was used to estimate intake. The $n$-alkane concentrations of the dosed pellets, feces, and herbage were determined as described by Dillon (1993).

\section{Chemical Analysis}

Herbage representative of that selected was sampled daily during measurement periods using a Gardena hand shears (Accu 60, Gardena International GmbH) as described above. The herbage samples were analyzed for DM content, ash $\left(500^{\circ} \mathrm{C}\right.$ furnace for $\left.12 \mathrm{~h}\right)$, CP (Leco FP-428, Australia Pty Ltd., Castle Hill, New South Wales, Australia), ADF, NDF, acid detergent lignin (Ankom Technology, Macedon, NY), and OMD (Fibertec Systems, Foss, Ballymount, Dublin 12, Ireland). Gross energy (GE) was determined on pelletized samples using a bomb calorimeter (Parr Instrument Co., Moline, IL).

\section{Statistical Analysis}

All statistical analyses were carried out using SAS software (SAS Institute, 2005). All herbage data were analyzed by ANOVA using the terms for treatment and paddock.
Animal variables were analyzed by covariate analysis. Daily milk yield, milk composition, $\mathrm{CH}_{4}, \mathrm{BW}$, and $\mathrm{BCS}$ were analyzed for each measurement period using the following model:

$$
Y_{i j k}=u+P_{i}+T_{j}+b_{1} X_{i j k}+b_{2} D I M_{i j k}+e_{i j k},
$$

where $Y_{i j k}$ represents the response of animal in parity $i$ offered treatment $j ; u=$ mean; $P_{i}=$ parity $(i=1$ to $2) ; T_{j}=$ treatment $(j=1$ to 2$) ; b_{1} X_{i j k}=$ the respective preexperimental milk output or $\mathrm{BW} / \mathrm{BCS}$ variable; $b_{2} D I M_{i j k}=$ days in milk; and $e_{i j k}=$ residual error term.

The preexperimental variables, used as covariates, were measured from March 29 to April 12, the $3 \mathrm{wk}$ before the animals were assigned to their treatments. Both M1 and M2 were analyzed separately.

\section{RESULTS}

\section{Grass Chemical Composition}

Table 1 shows the chemical composition of the consumed herbage for both measurement periods. There was no difference between the LHM and HHM treatments for NDF or ADF content during either measurement period. There was a tendency for higher lignin content in the LHM swards in M1. During M2 the lignin content of the LHM swards was $10 \mathrm{~g} / \mathrm{kg}$ higher $(P<0.05)$ than that in the HHM swards. During M1, there was a tendency for higher $(+10 \mathrm{~g} / \mathrm{kg} ; P=0.09)$ OMD content in the LHM swards $(859 \mathrm{~g} / \mathrm{kg})$. During M2, the OMD content of the LHM sward $(849 \mathrm{~g} / \mathrm{kg})$ was $12 \mathrm{~g} / \mathrm{kg}(P<0.05)$ higher than that of the HHM swards. The HHM swards had a lower $(P<0.001) \mathrm{CP}$ content in both M1 $(-64 \mathrm{~g} / \mathrm{kg})$ and M2 $(-35 \mathrm{~g} / \mathrm{kg})$. In terms of ash content, the LHM swards contained greater ash content $(P<0.01)$ in both $\mathrm{M} 1(+11 \mathrm{~g} / \mathrm{kg})$ and M2 $(+11 \mathrm{~g} / \mathrm{kg})$ compared with the HHM swards, which contained 81 and $88 \mathrm{~g} / \mathrm{kg}$ in M1 and M2, respectively. The LHM swards had a greater $(+0.3 \mathrm{MJ} / \mathrm{kg}$ of DM; $P<0.01)$ GE content in M1 but no difference was observed in M2.

\section{Pasture Measurements}

Table 2 shows the herbage measurements from the 2 measurement periods. During M1, herbage mass was $+969 \mathrm{~kg}$ of $\mathrm{DM} /$ ha $(P<0.001)$, pregrazing sward height $+5.1 \mathrm{~cm}(P<0.001)$, and rotation length +9.2 $\mathrm{d}(P<0.001)$ for the HHM compared with the LHM treatment. Postgrazing sward height was lower for the LHM treatment $(-0.4 \mathrm{~cm} ; P<0.001)$. All sward canopy characteristics favored higher intake in the LHM sward compared with the HHM sward: leaf proportion 
Table 1. Chemical composition of the consumed herbage during measurement 1 and measurement $2^{1}$ for low (1,000 kg of DM/ha) and high $(2,200 \mathrm{~kg}$ of DM/ha) herbage mass treatments

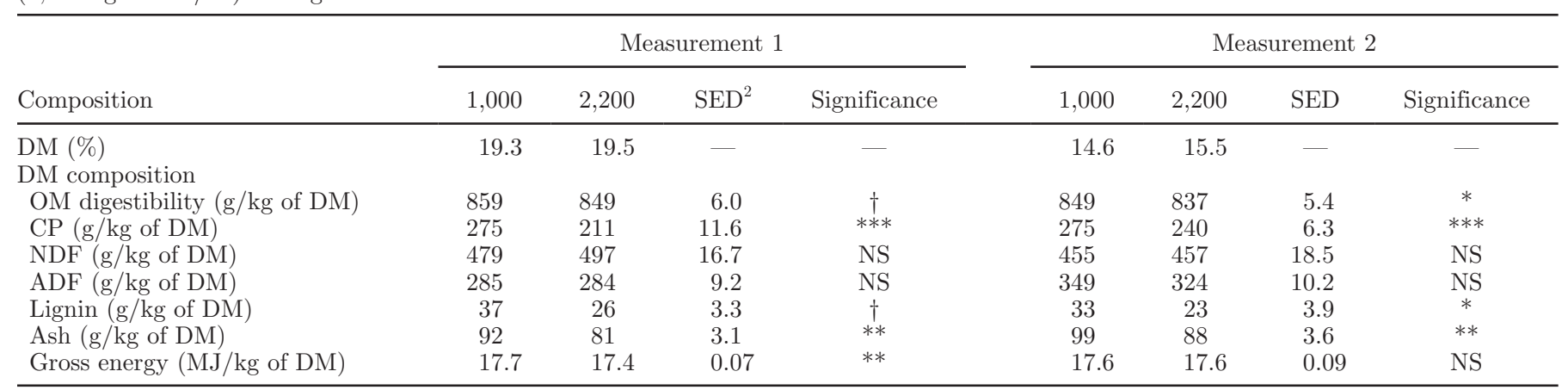

${ }^{1}$ Measurement 1 = June 21-26; measurement 2 = July12-17.

${ }^{2} \mathrm{SE}$ of the difference.

$* * * P<0.001 ;{ }^{* *} P<0.01 ;{ }^{*} P<0.05 ; \dagger P<0.1$.

$(+0.08 ; P<0.001)$, stem proportion $(-0.03 ; P<0.05)$, and dead proportion $(-0.05 ; P<0.001)$. Stem allowance was greater $(+0.7 \mathrm{~kg} \mathrm{DM} /$ cow; $P<0.001)$ for the HHM treatment and dead allowance was also greater $(+1.1 \mathrm{~kg} \mathrm{DM} /$ cow $P<0.001)$ for the HHM treatment. Treatment had no effect on leaf allowance during M1. In M2, pregrazing herbage mass $(+867 \mathrm{~kg} \mathrm{DM} /$ ha; $P<$ $0.001)$, pregrazing sward height $(+4.9 \mathrm{~cm} ; P<0.001)$, and rotation length $(+10 \mathrm{~d} ; P<0.001)$ were all greater for the HHM treatment. There was no effect of treatment on postgrazing sward height in M2. Leaf proportion continued to be higher $(+0.17 ; P<0.001)$ and stem and dead proportions lower $(-0.13 ; P<0.001$ and $-0.04 ; P<0.01$ respectively) for the LHM swards. The LHM treatment had higher leaf allowance $(+1.9 \mathrm{~kg}$ of $\mathrm{DM} ; P<0.01)$, lower stem allowance $(-2.3 \mathrm{~kg}$ of DM/ cow, $P<0.001)$, and lower dead allowance $(-0.6 \mathrm{~kg}$ of
$\mathrm{DM} /$ cow, $P<0.01)$ than the HHM treatment during M2. Daily herbage allowance was similar for both treatments throughout the experimental period.

\section{Animal Performance}

Table 3 shows the animal performance parameters measured during both measurement periods. Treatment did not affect animal performance with the exception of milk fat content in M1 and BCS during M2. During M1, cows grazing the HHM swards had a higher milk fat content $(+2.3 \mathrm{~g} / \mathrm{kg} ; P<0.05)$ compared with cows grazing the LHM swards $(36.1 \mathrm{~g} / \mathrm{kg})$. During M2, cows on the LHM treatment had a higher BCS $(+0.07 ; P<$ $0.05)$ than cows on the HHM treatment (2.95). None of the other parameters measured differed $(P>0.05)$ between treatments.

Table 2. Effect of herbage mass on pre- and postgrazing height; daily herbage allowance (DHA); leaf, stem, and dead proportions; and leaf, stem, and dead herbage allowance during measurement 1 and measurement 2 for low (1,000 kg of DM/ha) and high (2,200 kg of DM/ha) herbage mass treatments

\begin{tabular}{|c|c|c|c|c|c|c|c|c|}
\hline Item & \multicolumn{4}{|c|}{ Measurement $1^{1}$} & \multicolumn{4}{|c|}{ Measurement 2} \\
\hline Pregrazing herbage mass (kg of DM/ha) & 1,076 & 2,045 & 59.6 & $* * *$ & 1,074 & 1,941 & 54.7 & $* * *$ \\
\hline Postgrazing height $(\mathrm{cm})$ & 4.1 & 4.5 & 0.06 & $* * *$ & 3.9 & 4.1 & 0.09 & NS \\
\hline DHA $(\mathrm{kg}$ per cow $/ \mathrm{d})$ & 15.8 & 16.6 & 0.48 & NS & 15.5 & 16.6 & 0.66 & NS \\
\hline Leaf proportion & 0.73 & 0.65 & 0.129 & $* * *$ & 0.79 & 0.62 & 0.156 & $* * *$ \\
\hline Stem allowance ( $\mathrm{kg}$ of DM per cow/d) & 3.0 & 3.7 & 0.13 & $* * *$ & 1.8 & 4.1 & 0.14 & $* * *$ \\
\hline Dead allowance (kg of DM per cow/d) & 1.2 & 2.3 & 0.08 & $* * *$ & 1.4 & 2.0 & 0.15 & $* *$ \\
\hline Rotation length (d) & 13.7 & 22.9 & 0.46 & $* * *$ & 12.2 & 22.2 & 0.75 & $* * *$ \\
\hline
\end{tabular}

${ }^{1}$ Measurement 1 = June 21-26; measurement 2 = July12-17.

${ }^{2} \mathrm{SE}$ of the difference.

${ }^{* * *} P<0.001 ;{ }^{* *} P<0.01 ;{ }^{*} P<0.05$. 
Table 3. Effect of herbage mass on animal performance, grass intake, and methane production during measurement 1 and measurement 2 for low (1,000 kg of DM/ha) and high (2,200 kg of DM/ha) herbage mass treatments

\begin{tabular}{|c|c|c|c|c|c|c|c|c|}
\hline \multirow[b]{2}{*}{ Item } & \multicolumn{4}{|c|}{ Measurement $1^{1}$} & \multicolumn{4}{|c|}{ Measurement 2} \\
\hline & 1,000 & 2,200 & $\mathrm{SED}^{2}$ & Significance & 1,000 & 2,200 & SED & Significance \\
\hline \multicolumn{9}{|l|}{ Animal performance } \\
\hline Milk yield $(\mathrm{kg} / \mathrm{d})$ & 22.2 & 21.5 & 0.90 & NS & 18.0 & 17.0 & 0.77 & NS \\
\hline Milk fat $(\mathrm{g} / \mathrm{kg})$ & 36.1 & 38.4 & 0.12 & $*$ & 413 & 4.20 & 0.11 & NS \\
\hline Milk protein $(\mathrm{g} / \mathrm{kg})$ & 33.3 & 33.2 & 0.05 & NS & 33.2 & 32.8 & 0.06 & NS \\
\hline Milk lactose ( $\mathrm{g} / \mathrm{kg})$ & 45.1 & 45.9 & 0.05 & NS & 45.6 & 45.4 & 0.06 & NS \\
\hline $\mathrm{BCS}$ & 2.77 & 2.89 & 0.152 & NS & 3.02 & 2.95 & 0.035 & $*$ \\
\hline Grass DMI (kg/cow per d) & 16.9 & 15.4 & 0.41 & $*$ & 14.6 & 14.6 & 0.45 & NS \\
\hline \multicolumn{9}{|l|}{ Methane production } \\
\hline $\mathrm{g}$ of $\mathrm{CH}_{4} /$ cow per $\mathrm{d}$ & 286 & 286 & 16.18 & NS & 278 & 320 & 12.71 & $* *$ \\
\hline $\mathrm{g}$ of $\mathrm{CH}_{4} / \mathrm{kg}$ of milk yield & 13.0 & 13.6 & 0.90 & NS & 16.4 & 19.9 & 1.21 & $* *$ \\
\hline $\mathrm{g}$ of $\mathrm{CH}_{4} / \mathrm{kg}$ of milk solids & 187 & 192 & 10.6 & NS & 219 & 266 & 15.9 & ** \\
\hline $\mathrm{g}$ of $\mathrm{CH}_{4} / \mathrm{kg}$ of grass DMI & 17.0 & 18.7 & 0.06 & NS & 19.2 & 22.3 & 0.06 & * \\
\hline
\end{tabular}

${ }^{1}$ Measurement 1 = June 21-26; measurement 2 = July12-17.

${ }^{2} \mathrm{SE}$ of the difference.

${ }^{3}$ Gross energy.

${ }^{* *} P<0.01 ; * P<0.05 ; \dagger P<0.1$.

\section{GDMI and $\mathrm{CH}_{4}$ Production}

Table 3 shows the GDMI and the $\mathrm{CH}_{4}$ production for both measurement periods. Cows grazing on the LHM treatment in M1 had higher $(+1.5 \mathrm{~kg}$ of DM; $P<0.05)$ GDMI compared with those on the HHM treatment (15.4 kg of DM). In M2, GDMI was similar between treatments $(14.6 \mathrm{~kg}$ of $\mathrm{DM})$.

Methane emissions were similar, per cow and per unit of milk production, for M1. There was no effect of sward herbage mass on $\mathrm{CH}_{4}$ emissions per kilogram of GDMI in M1. During M1, when $\mathrm{CH}_{4}$ was expressed as a proportion of GE intake (GEI) lost, cows grazing the HHM swards lost a greater proportion of their GEI as $\mathrm{CH}_{4}(+0.9 \% ; P<0.05)$. Cows grazing the HHM swards had greater $\mathrm{CH}_{4}$ emissions during $\mathrm{M} 2(P<0.01 ;+42$ $\mathrm{g}$ of $\mathrm{CH}_{4} /$ cow per day) than the cows grazing the LHM swards (278 $\mathrm{g}$ of $\mathrm{CH}_{4} /$ cow per day). Cows grazing the HHM swards also had greater $\mathrm{CH}_{4}$ emissions when expressed per unit of milk yield (MY) during M2. During M2, cows on the HHM treatment produced $3.5 \mathrm{~g}$ of $\mathrm{CH}_{4} / \mathrm{kg}$ of MY $(P<0.01)$ more than cows on the LHM treatment (16.4 g of $\mathrm{CH}_{4} / \mathrm{kg}$ of MY). A similar effect was observed for $\mathrm{CH}_{4}$ production per kilogram of milk solids (MS), where cows on the HHM treatment had greater $\mathrm{CH}_{4}$ emissions $\left(+47 \mathrm{~g}\right.$ of $\mathrm{CH}_{4} / \mathrm{kg}$ of MS; $P<$ 0.01) compared with cows on the LHM treatment (219 $\mathrm{g}$ of $\mathrm{CH}_{4} / \mathrm{kg}$ of MS). In M2, cows grazing the LHM swards had lower $\mathrm{CH}_{4}$ emissions per unit intake $(-3.1$ g of $\mathrm{CH}_{4} / \mathrm{kg}$ of GDMI, $\left.P<0.05\right)$ compared with their counterparts on the HHM swards. Cows grazing the
LHM swards in M2 had lower $\mathrm{CH}_{4}$ emissions when expressed as a proportion of GEI lost $(-1 \% ; P<0.05)$.

\section{DISCUSSION}

\section{Grass Quality}

The swards used in this study were 85 to $90 \%$ perennial ryegrass. On-farm, one would expect much lower proportions of perennial ryegrass in swards because of the low level of sward reseeding reported by Creighton et al. (2009).

Grass quality is expected to increase with decreasing HM. Hoogendoorn et al. (1992) stated that low pregrazing HM swards contained higher proportions of leaf, lower proportions of stem and dead material, and higher OMD values. The OMD concentration in the leaf fraction is higher than that in live stem and dead material (Tilley and Terry, 1963). In the current study the leaf proportions were significantly higher in the LHM swards compared with the HHM swards in M1 and M2, accounting for the higher OMD values observed with the LHM swards. The HHM swards in M2 were reflective of very poor grazing management and an effort had to be made to ensure this reduction in grass quality. Stakelum and O'Donovan (1998) reported that a 5.5\% change in leaf content is equal to a 1-unit change in digestibility. Stakelum and Dillon (2007) reported that as herbage increased, OMD content and leaf proportions decreased, which is in agreement with the findings of the current study. 
The CP of the consumed sward was consistently higher, $+64 \mathrm{~g} / \mathrm{kg}$ of DM in M1 and $+35 \mathrm{~g} / \mathrm{kg}$ of DM in M2, for the LHM compared with the HHM. The higher $\mathrm{CP}$ concentration in the LHM swards also contributed to the higher OMD of those swards in M2.

No significant difference was observed in either measurement period for ADF and NDF content, and no difference was observed in lignin content in M1. In M2, higher lignin content was observed in the LHM swards. These results contradict those of Osbourn (1980) who reported increasing fiber fractions, including lignin, with advancing maturity. The cellulose and hemicellulose fractions of the herbage were calculated and found to be not significantly different between the 2 treatments in either period.

\section{Animal Performance}

Contrasting reports can be found in the literature regarding the effect of $\mathrm{HM}$ on milk production, with this study reporting no significant difference in milk production between the treatments. Wales et al. (1999) reported lower milk production for cows grazing low HM swards $(3,100 \mathrm{~kg}$ of $\mathrm{DM} / \mathrm{ha})$ compared with medium HM swards $(4,900 \mathrm{~kg}$ of $\mathrm{DM} / \mathrm{ha})$. The current study was a short-term study and it can be concluded from the studies of both McEvoy et al. (2009) and Curran et al. (2010) that the beneficial effect of grazing lower HM swards is cumulative. Both authors reported that grazing lower HM swards leads to increased milk performance, particularly in the second half of the grazing season due to enhanced grass quality. Hence, this was not evident in the present short-term study. In addition, the high herbage mass achieved in both these studies (McEvoy et al., 2009: 2,200 kg of DM/ha; Curran et al., 2010: 2,400 $\mathrm{kg}$ of DM/ha) was higher than that in the current study (1,993 $\mathrm{kg}$ of DM/ha), which may also explain why no difference in milk production was observed in the current study. Other authors agree that animals grazing lower HM swards achieve higher milk performance because of the intake of higher quality herbage (Holmes et al., 1992; Stakelum and Dillon, 2007). Hoogendoorn et al. (1992) stated that low pregrazing HM swards contained higher proportions of grass leaf and lower proportions of stem and dead material, resulting in higher DM digestibility values and consequently greater milk production per cow.

\section{Grass Intake}

Curran et al. (2010) reported no difference in GDMI between cows grazing a low HM sward $(1,600 \mathrm{~kg}$ of $\mathrm{DM} / \mathrm{ha}$ ) compared with a high HM sward of $2,400 \mathrm{~kg}$ of $\mathrm{DM} /$ ha. Wales et al. (1999) reported increasing intake at higher levels of HM. Peyraud et al. (1996) reported that the increased HM of a sward increases intake primarily because cows have access to a greater proportion of easily harvestable material before they have to graze the deeper, stemmier horizons. These findings do not agree with the results of the current study where the cows grazing the LHM swards achieved higher grass intakes than those grazing the HHM swards in M1. Our findings are in agreement with the findings of Jamieson (1975) and Hodgson and Wilkinson (1968) who reported a decline in herbage intake for high HM swards. O'Donovan and Delaby (2008) suggested that maintaining lower levels of $\mathrm{HM}$ is likely to increase GDMI because of higher proportions of leaf and lower proportions of stem and dead material. Maintaining low HM results in higher OMD values (Hoogendoorn et al., 1992), and GDMI increases as the digestibility of a sward is increased (Stakelum and Dillon, 1990). This would agree with the findings during M1 when the LHM swards tended to have significantly higher OMD and higher levels of leaf. Laredo and Minson (1975) found that the voluntary DMI of the leaf fraction is $20 \%$ higher than that of the stem fraction. Wade (1991) found that increasing levels of sward stem (true and pseudostem) was a barrier to increasing grass intake, which is in agreement with the current study, where HHM swards had higher proportions of stem and subsequently lower GDMI in M1. During M2, intake declined for both treatments, with no difference between treatments in terms of grass intake $(14.6 \mathrm{~kg}$ of $\mathrm{DM} /$ cow per day). This was unexpected considering that the LHM group was offered a greater proportion of leaf during M2 compared with M1. However, the cows grazed to a lower postgrazing height in M2, which may have restricted their GDMI.

\section{Methane Production}

Limited information is available in the literature on $\mathrm{CH}_{4}$ production from grazing dairy cows and little on quantifying the effects of HM or herbage quality on $\mathrm{CH}_{4}$ production. Data from beef cattle indicate that beef heifers offered zero-grazed grass differing in pregrazing $\mathrm{HM}$ did not differ in intake-corrected $\mathrm{CH}_{4}$ emissions (Hart et al., 2009). When animal performance was measured in a subsequent grazing study, the authors reported a tendency for reduced $\mathrm{CH}_{4}$ emissions per kilogram of live weight gain (Boland et al., 2009) for animals offered a low HM sward. It should be noted that in the latter study, the low HM treatment was equivalent to the HHM treatment in the current study and the high HM treatment was of the order of 3,800 $\mathrm{kg}$ of DM/ha $(>4 \mathrm{~cm})$. 
Differences were observed in the leaf, stem, and dead proportions between treatments and a difference in regrowth interval was recorded. The difference in sward structure and regrowth interval led to differences in chemical composition between the treatments. A greater OMD value was recorded in the LHM swards in M2. This has already been attributed to the higher leaf fraction and higher CP content of the LHM swards in M2. Blaxter and Clapperton (1965) reported that at high intake levels (2 and 3 times maintenance feeding level), $\mathrm{CH}_{4}$ production decreases with increasing digestibility. These findings are in agreement with the current study where cows grazing more digestible LHM swards in M2 produced less $\mathrm{CH}_{4}$. Feeding levels were in excess of maintenance for both treatments. The LHM swards in M2 contained higher levels of $\mathrm{CP}$ and lignin as previously discussed. A study conducted by Moe and Tyrrell (1979) in which total $\mathrm{CH}_{4}$ production was related to the intake of several plant fractions reported nonsignificant terms for $\mathrm{CP}$ and lignin related to total $\mathrm{CH}_{4}$ production. This also agrees with the current study in which the LHM swards contained higher levels of $\mathrm{CP}$ and lignin, which resulted in lower $\mathrm{CH}_{4}$ production.

The average $\mathrm{CH}_{4}$ emissions reported in this study (293 $\mathrm{g}$ of $\mathrm{CH}_{4} /$ cow per day) are similar to those of Lassey et al. (1997), who reported $262 \mathrm{~g}$ of $\mathrm{CH}_{4} /$ cow per day for cows grazing pasture. Several authors reported that feed intake is the greatest driver of $\mathrm{CH}_{4}$ production (Blaxter and Clapperton, 1965; McCaughey et al., 1997, 1999; Hart et al., 2009). This would explain the lower $\mathrm{CH}_{4}$ production reported in the study of Pinares-Patiño et al. (2003; $235 \mathrm{~g}$ of $\mathrm{CH}_{4} /$ cow per day), who demonstrated low intakes from Charolais cows grazed on a monospecific pasture of timothy at 4 stages of maturity, compared with the current study. It also explains the much higher $\mathrm{CH}_{4}$ production reported by Robertson and Waghorn $\left(2002 ; 361 \mathrm{~g}\right.$ of $\mathrm{CH}_{4} /$ cow per day) for cows grazing pasture at a similar stage of lactation $(150 \mathrm{~d})$. The cows on that study (Robertson and Waghorn, 2002) attained intakes of $17.5 \mathrm{~kg}$ of $\mathrm{DM} / \mathrm{d}$, which was higher than the intake attained on this study $(15.4 \mathrm{~kg}$ of DM/d). Although intake is a major driver of $\mathrm{CH}_{4}$ production, it is clear from the current study that other factors are involved in driving $\mathrm{CH}_{4}$ production in the grazing animal, as we found that $\mathrm{CH}_{4}$ per unit intake differed between treatments.

When evaluating $\mathrm{CH}_{4}$ expressed as a proportion of GDMI, we can evaluate the effect of the diet offered to the cows in this study. In terms of $\mathrm{CH}_{4}$ per kilogram of GDMI, this study reported a mean value of $19.3 \mathrm{~g}$ of $\mathrm{CH}_{4} / \mathrm{kg}$ of GDMI, which is slightly lower than the values reported by Robertson and Waghorn (2002) and Lassey et al. (1997), who reported $21 \mathrm{~g}$ and $20 \mathrm{~g}$ of $\mathrm{CH}_{4} /$ $\mathrm{kg}$ of GDMI, respectively, for grazing cows. It is more important to observe the higher $\mathrm{CH}_{4}$ production per kilogram of GDMI with the HHM treatment compared with the LHM treatment in M2. Beever (1993) suggested a higher $\mathrm{CH}_{4}$ yield from more mature pasture. This agrees with the findings of the current study, where it is clear that the observed difference was due to differences in grass composition as discussed previously.

Johnson et al. (1993) reported that $\mathrm{CH}_{4}$ losses vary from approximately 2 to almost $12 \%$ of GEI. Johnson et al. (1994) found that as diet digestibility increases, variability in $\mathrm{CH}_{4}$ loss also increases. The mean percentage of GEI lost as $\mathrm{CH}_{4}$ in this study was $6.4 \%$, ranging from $5.4 \%$ for LHM in M1 to $7.4 \%$ for HHM in M2. These results agree with the studies of Robertson and Waghorn (2002) and Pinares-Patiño et al. (2003), who reported losses of 6.3 and $6.4 \%$ of GEI lost as $\mathrm{CH}_{4}$, respectively, from cows grazing pasture in summer. The study of McCaughey et al. (1999) reported a higher level of GEI lost as $\mathrm{CH}_{4}(9.5 \%)$ for lactating beef cows on a grass diet. The grass pastures in the study of McCaughey et al. (1999) consisted of $100 \%$ meadow bromegrass, which was of lesser quality in terms of OMD than the grass offered in the current study, thereby accounting for the higher loss of GEI as $\mathrm{CH}_{4}$. Robertson and Waghorn (2002) observed that $\mathrm{CH}_{4}$ production from dairy cows grazing pastures in September (spring) was 4.5 to $5.3 \%$ of GEI, whereas it increased to 6 to $7 \%$ of GEI when cows grazed in December (summer) of the same season. This follows the same trend as in the current study, where higher losses of GEI as $\mathrm{CH}_{4}$ were reported in M2 than in M1. Robertson and Waghorn (2002) stated that grass maturity accounted for the increased proportion of GEI lost as $\mathrm{CH}_{4}$ from cows over the lactation period, which fully agrees with the findings of the current study. This is illustrated by the fact that in both periods of this study there were negative effects of the HHM swards on the proportion of GEI lost as $\mathrm{CH}_{4}$. Cows grazing the HHM swards lost approximately $14 \%$ more of their GEI as $\mathrm{CH}_{4}$ compared with cows grazing the LHM swards. This was due to lower DMI but similar $\mathrm{CH}_{4}$ production of HHM cows in M1 and to higher $\mathrm{CH}_{4}$ production per cow but similar DMI on the HHM treatment in M2. Differences in grass maturity were obtained in this study by varying the regrowth interval between the swards. In general, the HHM swards had a 10-d longer regrowth interval, which translated to a difference in grass quality in terms of OMD. There were differences in sward profile of the 2 treatments in both measurement periods; the type of sward offered to the HHM cows in M2 was very different with less leaf on offer, which translated to a much greater loss of GEI as $\mathrm{CH}_{4}$.

Robertson and Waghorn (2002) and Lassey et al. (1997) reported values of $18.4 \mathrm{~g}$ and $18.6 \mathrm{~g}$ of $\mathrm{CH}_{4} / \mathrm{kg}$ 
of MY, respectively, which are higher than the mean value reported in this study ( $15.7 \mathrm{~g}$ of $\mathrm{CH}_{4} / \mathrm{kg}$ of $\mathrm{MY}$ ). In the study of Robertson and Waghorn (2002), higher daily $\mathrm{CH}_{4}$ accounts for the higher $\mathrm{CH}_{4}$ production per kilogram of milk yield, making the current study more efficient in terms of $\mathrm{CH}_{4}$ emissions per output of milk. In the study of Lassey et al. (1997), the higher $\mathrm{CH}_{4}$ production per kilogram of MY can be attributed to the relatively poor milk production performance attained in the study. In M2 of the current study, the LHM treatment was more efficient in terms of $\mathrm{CH}_{4}$ emissions per output of milk and milk solids. This can attributed to the reduced $\mathrm{CH}_{4}$ production due to the mechanisms described above, because production was similar between treatments.

\section{CONCLUSIONS}

This study demonstrated that maintaining low HM swards has benefits in terms of grass quality and environmental sustainability. Results from this study indicate that cows grazing low HM swards produced less $\mathrm{CH}_{4}$ per cow, per kilogram of milk, per kilogram of milk solids, and per kilogram of GDMI through intake of higher quality grass. Cows grazing the low HM swards lost a lower proportion of their GEI as $\mathrm{CH}_{4}$, demonstrating the benefit of grazing low HM swards to improve the GHG efficiency of milk production from pasture. This study found that implementing good grazing management reduced GEI loss as $\mathrm{CH}_{4}$ by $14 \%$. Thus, implementing good grazing management at the farm level is a suitable mitigation strategy for reducing $\mathrm{CH}_{4}$ production from dairy cows.

\section{REFERENCES}

Beever, D. E. 1993. Rumen function. Pages 187-215 in Quantitative Aspects of Ruminant Digestion and Metabolism. J. M. Forbes and J. France, ed. CAB International, Wallingford, UK.

Blaxter, K. L., and J. L. Clapperton. 1965. Prediction of the amount of methane produced by ruminants. Br. J. Nutr. 19:511-522.

Boland, T. M., K. J. Hart, K. M. Pierce, B. M. Lynch, R. McDonnell, D. Murphy, A. K. Kelly, and D. A. Kenny. 2009. The effect of pregrazing herbage mass on growth rate and methane emissions of grazing beef cattle. J. Dairy Sci. 92(E-Suppl. 1):343.

Casey, J. W., and N. M. Holden. 2005. Analysis of greenhouse gas emissions from the average Irish milk production system. Agric. Syst. 86:97-114.

Creighton, P., K. Kennedy, L. Shalloo, T. M. Boland, and M. O' Donovan. 2009. A survey analysis of grassland dairy farming in Ireland and the factors affecting its success at farm level. Page 76 in Proc. Agric. Res. Forum 2009, Tullamore, Co. Offaly, Ireland. Teagasc, Oak Park, Co. Carlow, Ireland.

Curran, J., L. Delaby, E. Kennedy, J. P. Murphy, T. M. Boland, and M. O'Donovan. 2010. Sward characteristics, grass dry matter intake and milk production performance are affected by pre-grazing herbage mass and pasture allowance. Livest. Sci. 127:144-154.

Dillon, P. 1993. The use of n-alkanes as markers to determine intake, botanical composition of available or consumed herbage in studies of digesta kinetics with dairy cows. PhD Thesis. National University of Ireland, Dublin, Ireland.

Dillon, P., and G. Stakelum. 1989. Herbage and dosed alkanes as a grass management technique for dairy cows. Ir. J. Agric. Res. 8:104. (Abstr.)

European Community. 2002. Statutory Instrument No. 566 of 2002 European Communties (Amendment of Cruelty to Animals Act 1876) Regulations 2002. The Stationery Office, Dublin, Ireland.

Hammond, K. J., S. Muetzel, G. C. Waghorn, C. S. Pinares-Patino, J. L. Burke, and S. O. Hoskin. 2009. The variation in methane emissions from sheep and cattle is not explained by the chemical composition of ryegrass. Proc. N.Z. Soc. Anim. Prod. 69:174-178.

Hart, K. J., P. G. Martin, P. A. Foley, D. A. Kenny, and T. M. Boland. 2009. Effect of sward dry matter digestibility on methane production, ruminal fermentation, and microbial populations of zero-grazed beef cattle. J. Anim. Sci. 87:3342-3350.

Hodgson, J., and J. M. Wilkinson. 1968. The influence of the quantity of herbage offered and its digestibility on the amount eaten by grazing cattle. J. Br. Grassl. Soc. 23:75-80.

Holmes, C. W., C. J. Hoogendoorn, M. P. Ryan, and A. C. P. Chu. 1992. Some effects of herbage composition, as influenced by previous grazing management, on milk production by cows grazing on ryegrass/white clover pastures. 1. Milk production in early spring: Effects of different regrowth intervals during the preceding winter period. Grass Forage Sci. 47:309-315.

Hoogendoorn, C. J., C. W. Holmes, and A. C. P. Chu. 1992. Some effects of herbage composition, as influenced by previous grazing management, on milk production by cows grazing on ryegrass/ white clover pastures. 2. Milk production in late spring/summer: Effects of grazing intensity during the preceding spring period. Grass Forage Sci. 47:316-325.

Jamieson, W. S. 1975. Studies on the herbage intake and grazing behaviour of cattle and sheep. $\mathrm{PhD}$ thesis. University of Reading, Reading, UK.

Johnson, D. E., T. M. Hill, G. M. Ward, K. A. Johnson, M. E. Branine, B. R. Carmean, and D. W. Lodman. 1993. Principle factors varying methane emissions from ruminants and other animals. Pages 199-230 in Atmospheric Methane: Sources, Sinks and Role in Global Change. NATO ADI Series. Vol. 113. M. A. Khalil, ed Springer-Verlag, Berlin, Germany.

Johnson, K., M. Huyler, H. Westberg, B. Lamb, and P. Zimmerman. 1994. Measurement of methane emissions from ruminant livestock using a sulphur hexafluoride tracer technique. Environ. Sci. Technol. 28:359-362.

Johnson, K. A., H. H. Westberg, J. J. Michal, and M. W. Cossalman. 2007. The $\mathrm{SF}_{6}$ tracer technique: Methane measurement from ruminants. Pages 33-67 in Measuring Methane Production from Ruminants. H. P. S. Makkar and P. E. Vercoe, ed. Springer, New York, NY

Laredo, M. A., and D. J. Minson. 1975. The voluntary intake and digestibility by sheep of leaf and stem fractions of Lolium perenne. J. Br. Grassl. Soc. 30:73-77.

Lassey, K. R., M. J. Ulyatt, R. J. Martin, C. F. Walker, and I. David Shelton. 1997. Methane emissions measured directly from grazing livestock in New Zealand. Atmos. Environ. 31:2905-2914.

Lips, M., and P. Reider. 2005. Abolition of raw milk quota in the European Union: A CGE analysis at the member country level. J. Agric. Econ. 56:1-17.

Lovett, D. K., L. Shalloo, P. Dillon, and F. P. O'Mara. 2008. Greenhouse gas emissions from pastoral based dairying systems: The effect of uncertainty and management change under two contrasting production systems. Livest. Sci. 116:260-274.

Lowman, B. G., N. A. Scott, and S. H. Somerville. 1976. Condition scoring of cattle. Bulletin 6. East of Scotland College. Agric, Edinburgh, UK.

Mayes, R. W., C. S. Lamb, and P. A. Colgrove. 1986. The use of dosed herbage n-alkanes as markers for the determination of herbage intake. J. Agric. Sci. (Camb.) 107:161-170.

Mayne, C. S., R. D. Newberry, S. C. F. Woodcock, and R. J. Wilkins 1987. Effect of grazing severity on grass utilization and milk 
production of rotationally grazed dairy cows. Grass Forage Sci. 42:59-72.

Mc Gettigan, M., P. Duffy, E. Hyde, and P. O. Brien. 2009. National Inventory Report 2009. Greenhouse Gas Emissions 1990-2007 Reported to the United Nations framework convention on climate change. Environmental Protection Agency, Johnstown Castle Estate, Wexford, Ireland.

McCaughey, W. P., K. Wittenberg, and D. Corrigan. 1997. Methane production by steers on pasture. Can. J. Anim. Sci. 77:519-524.

McCaughey, W. P., K. Wittenberg, and D. Corrigan. 1999. Impact of pasture type on methane production by lactating beef cows. Can. J. Anim. Sci. 79:221-226.

McEvoy, M., M. O'Donovan, E. Kennedy, J. P. Murphy, L. Delaby, and T. M. Boland. 2009. Effect of pregrazing herbage mass and pasture allowance on the lactation performance of Holstein-Friesian dairy cows. J. Dairy Sci. 92:414-422.

Moe, P. W., and H. F. Tyrrell. 1979. Methane production in dairy cows. J. Dairy Sci. 62:1583-1586.

Monteny, J. G., A. Bannink, and D. Chadwick. 2006. Greenhouse gas abatement strategies for animal husbandry. Agric. Ecosyst. Environ. 112:163-170.

O'Brien, D., L. Shallo, C. Grainger, F. Buckley, B. Horan, and M. Wallace. 2010. The influence of strain of Holstein-Friesian cow and feeding system on greenhouse gas emissions from pastoral dairy farms. Page 73 in Proc. Br. Soc. Anim. Sci. and Agric. Res. Forum, Belfast, UK. Br. Soc. Anim. Sci., UK.

O'Donovan, M., and L. Delaby. 2008. Sward characteristics, grass dry matter intake and milk production performance is affected by timing of spring grazing and subsequent stocking rate. Livest. Sci. 115:158-168.

Osbourn, D. F. 1980. The feeding value of grass and grass products. Pages 89-129 in Grass, Its Production and Utilization. W. Holmes, ed. Blackwell, Oxford, UK.

Peyraud, J. L., E. A. Comeron, M. H. Wade, and G. Lemaire. 1996. The effect of daily herbage allowance, herbage mass and animal factors upon herbage intake by grazing dairy cows. Ann. Zootech. 45:201-217.
Pinares-Patiño, C. S., R. Baumont, and C. Martin. 2003. Methane emissions by Charolais cows grazing a monospecific pasture of timothy at four stages of maturity. Can. J. Anim. Sci. 83:769-777.

Robertson, L. J., and G. C. Waghorn. 2002. Dairy industry perspectives on methane emissions and production from cattle fed pasture or total mixed rations in New Zealand. Pages 213-218 in New Zealand Society of Animal Production, 1999. New Zealand Society of Animal Production.

SAS Institute. 2005. SAS User's Guide: Statistics. SAS Inst. Inc. Cary, NC.

Stakelum, G., and P. Dillon. 1990. Influence of sward structure and digestibility on the intake and performance of lactating and growing cattle. Pages 30-42 in Management Issues for Dairying in the 1990s. C. S. Mayne, ed. Br. Grassl. Soc., UK.

Stakelum, G., and P. Dillon. 2007. The effect of grazing pressure on rotationally grazed pastures in spring/early summer on subsequent sward characteristics. Ir. J. Agric. Food Res. 46:15-28.

Stakelum, G., and M. O'Donovan. 1998. Grazing severity, sward digestibility and intake, and farm cover targets for profitable summer milk production. Pages 1-16 in The Production of High Quality Milk from Grass and Other Feeds. Teagasc, Cahir, Co. Tipperary, Ireland.

Tilley, J. M. A., and R. A. Terry. 1963. A two-stage technique for the in vitro digestion of forage crops. J. Br. Grassl. Soc. 17:104-111.

Tyrrell, H. F., and J. T. Reid. 1965. Prediction of the energy value of cow's milk. J. Dairy Sci. 48:1215-1223.

Wade, M. H. 1991. Factors affecting the availability of vegetative $L o-$ lium perenne to grazing dairy cows with special reference to sward characteristics stocking rate and grazing method. $\mathrm{PhD}$ thesis. Université de Rennes, France.

Wales, W. J., P. T. Doyle, C. R. Stockdale, and D. W. Dellow. 1999 Effects of variations in herbage mass, allowance, and level of supplement on nutrient intake and milk production of dairy cows in spring and summer. Aust. J. Exp. Agric. 39:119-130. 